\title{
Awareness and Application of Personal Knowledge Management by Academic Librarians in University Libraries in South-East Nigeria
}

\author{
Anike, Angela N. ${ }^{1 *}$ Echedom, Anthonia U. ${ }^{2}$ \\ 1. Festus Aghagbo Nwako Library, Nnamdi Azikiwe University, Awka \\ 2. Department of Library and Information Science Nnamdi Azikwe University, Awka Nigeria
}

\begin{abstract}
This study investigated the level of awareness and application of personal knowledge management by academic librarians in university libraries in South-East Nigeria. Descriptive survey design was adopted for the study. The population comprised 175 academic librarians from ten public universities. Questionnaire was used as the instrument for data collection. Data collected were analyzed using descriptive and inferential statistics. Frequency counts and percentages were used for research question 1, arithmetic mean were used for research questions 2 and 3 . The study revealed among others that the level of awareness of personal knowledge management was moderate and the level of application of personal knowledge management was high. Challenges associated with application of personal knowledge management includes, difficulty in expressing tacit knowledge of individuals and lack of social network among others. The study recommended that university libraries should formulate a knowledge management strategy based on actual needs of the university.
\end{abstract}

Keywords: Awareness, Application, Personal knowledge Management, Academic Librarians.

DOI: $10.7176 / \mathrm{IKM} / 10-6-05$

Publication date:September $30^{\text {th }} 2020$

\section{Introduction}

Knowledge management (KM) is about building organizational intelligence by enabling people to improve the way they work in capturing, sharing and using knowledge. It involves using the ideas and experience of people and process to improve the organization's performance. Nwokocha, Unagha, Igwe, \& Ewah-Out (2015) posited that $\mathrm{KM}$ is a combination of values, experiences, information, individual's insight and understanding, and is not just what is present in the written or documented from within the organization but also in the practices, routines and processes as well as in the workforce of the organization.

The key idea driving knowledge management $(\mathrm{KM})$ is that knowledge is a strategic asset that must be managed. It should be managed as an asset or resource just like land, capital and labour. In the present information and knowledge era, knowledge as an intangible asset has taken precedence over traditional organizational resources such as capital and labour. KM has attracted a series of definitions, explanations and conceptualizations due to its interdisciplinary nature. However, it can be inferred that any attempt to define and conceptualize KM must take into account the two major types of knowledge (explicit and tacit) and the circumstances that led to the development of KM (Omotayo 2015, Igwe, Nnadozie \& Unagha 2015). Knowledge management involves the organization and harnessing of the knowledge assets in order to achieve individual and corporate goals.

In the current knowledge environment, it has become essential for individuals to maintain, develop and market their skills to gain a competitive advantage in the job market in both the short and long term. Jain (2011) viewed personal knowledge management (PKM) as managing and maintaining personal knowledge which a person already has to enrich an individual knowledge database. It will enable the individual to retrieve knowledge timeeffectively so as to use, re-use and mobilize it for personal benefit or benefit of the organization or the community. PKM is a tool which can equip knowledge workers with the necessary skills to manage their knowledge.

PKM plays a vital role in the KM process both for the individual and the organization. PKM is about selfeffectiveness and making people more valuable to the organization that they are working in and consequently, creating more value for individual employees. Individuals are the leading knowledge creators in organizations and managing their knowledge can create value for both individuals and organizations.

University libraries are libraries that belong to universities. The mission of university libraries is to support the educational and research activities of their parent institution through the provision of collections, services and user 
education. University libraries embrace vast amounts of knowledge in various areas, and its management is considered necessary for providing quality information services, making effective decisions, improving their overall performance and becoming more relevant to their parent institutions. Academic librarianship, according to Moran and Leonard (2010), is the profession practiced by those working in libraries associated with institutions of higher education of various types or tertiary educational institutions, including universities. The primary responsibility of academic librarians is to support the teaching, learning, and research efforts of the parent institution's faculty and students. They fulfill this mission by working with faculty, staff, and students in finding the information they need and by selecting, acquiring, organizing, providing access to and preserving the library's collection. Moran and Leonard (2010) stressed that academic librarianship today demands much more thought and effort on connecting with users and maintaining their engagement. Maponya (2004) observed that in this age of significant change in information formats, delivery models and technologies academic librarian can no longer meet the information needs of the users through the traditional avenue of merely adding to their library collections. Academic librarians should extend their information management roles and enhance their management competencies. These changes demand new competencies in academic librarians as a result academic librarians had to know the interrelationship between characteristics of knowledge and process of knowledge and knowledge management in the academic library.

\section{Statement of the Problem}

Knowledge management seeks to extend the role of the librarians to manage all types of knowledge both explicit and tacit for the benefit of the library. KM is generally understood to mean the sharing of knowledge inside or outside an organization. This sharing of knowledge seems to be taken for granted in university libraries in SouthEast (SE) Nigeria. Most times, knowledge that is held by individuals leaves when they resign or retire from the organization. Most staff of university libraries in SE Nigeria is frequently sponsored by their university to be trained in workshops or conferences but on their return will not transfer the knowledge to the organization. Knowledge that is acquired outside the organization frequently remains with the individual because it is not transferred to other employees. Librarians do not typically pass on knowledge from trainings they participated in or document the new knowledge they gain from conference presentation for dissemination to their colleagues. Acquired knowledge should ideally be shared in meetings or through special seminars, discussions or documented.

Again, in university libraries in SE Nigeria, academic librarians and other library staff have specific duties and ways of performing them. In a number of cases, there are vital knowledge resting with one individual and little is done to tap this knowledge and make it more accessible. In case of retirement, resignation or death of such individual, knowledge in performing certain duties are lost. These negative trends could be due to the level of awareness and application of knowledge management by the librarians in these universities which is not clearly known. It is, therefore, imperative to conduct this study to determine the level of awareness and application of knowledge management among academic librarians in SE university.

\subsection{Purpose of the Study}

The main purpose of the study is to determine the level of awareness and application of personal knowledge management by academic librarians in university libraries in South- East, Nigeria. Specifically, the study sought to:

1. Identify the level of awareness of PKM among academic librarians in SE, Nigeria;

2. Find out the level of application of PKM among academic librarians in SE, Nigeria;

3. Identify the challenges associated with the application of PKM among academic librarians in SE, Nigeria.

\subsection{Research Questions}

The study was meant to supply answers to the following questions:

1. What is the level of awareness of PKM among academic librarians in SE, Nigeria?

2. What is the level of application of PKM among academic librarians in SE, Nigeria?

3. What are the Challenges associated with the application of PKM among academic librarians in SE, Nigeria? 


\section{Review of Related Literature}

\subsection{Awareness of Personal Knowledge Management}

In this global economy, economic activities have shifted from people working with their hands, to people working with their heads, from tangible resources like steel to intangible resources like knowledge (Boom \& Pimentel, 2009). Maponya (2004) posited that, knowledge is essential in any organization. The organization internalizes only a part of knowledge, the other is internalized by individuals that work in the organization. These individual members of the organization should be aware on how to manage and maintain their knowledge to enable them to retrieve them effectively so as to use, re-use and mobilize it for the benefit of the person and the organization.

Jain (2011), observed that PKM has been in the background since the early days of KM. However, in the past two years, people have begun to recognize the importance of PKM, and there are several activities around PKM: blogs, workshops, conferences, e-book and online surveys. All these are indications of growing awareness and recognition of PKM. Verma (2009), believed that a great deal of organizational knowledge resides in the individual employees' heads and individual databases. KM research emphasizes extracting knowledge from people instead of encouraging them to manage their knowledge. Jain (2011) posited that knowledge workers spend much time looking for valuable information which is already in their possession, and this lowers their productivity. They do these because they are not aware of PKM.

From some research findings, it was observed that knowledge workers spend much time sifting through irrelevant information to find what they need. These indicates lack of awareness of PKM and its benefits to the workers. Most of them wished that they could spend less time organizing information and more time using the information that comes their way (Anklam 2009, Jain 2011). Jain (2011), posited that these are indications of how personal knowledge, time management and productivity are tied up in PKM. Jain further stated that organizations should realize that employees waste much of their time in tracing useful information that it would be better if they create awareness on PKM that could lead to greater organizational success.

Michailova and Nielsen (2009) averred that awareness of personal knowledge assumed to be the key asset, the effective exploitation of which determines success for the organization. Knowledge is of limited organizational value if it is not shared. The ability to collect, integrate and apply specialized knowledge of an organization's members are therefore fundamental to an organization's ability to create and sustain competitive advantage. Specifically, Nwokocha et al. (2015) posited that the awareness of PKM by academic librarians would enable them to identify how much knowledge and information they possess, how they can access the things they know, strategies they can apply in acquiring new knowledge, strategies for accessing new knowledge and ability to understand oneself.

\subsection{Application of Personal Knowledge Management in University Libraries}

PKM is about moving beyond finding information to being able to organize and construct meaning from the vast amount of resources available. Application of PKM, according to Avery, Brooks, Brown, Dorsey and O'Conner (2010), entails sharing both intelligent practices that guide the use of tools as well as intelligent and efficient use of the tools themselves. In that PKM is based on a set of problem-solving skills that have both a logical as well as a hands-on component. PKM environments integrate individual work environments and infrastructures to support joint creation, distribution, sharing and application of knowledge.

In PKM application, Nazim and Mukherjee (2012), posited that the librarian must be able to integrate the personal know-how with the organizational processes in achieving the organization's goals and objectives. Omotayo (2015), noted that as information managers in the universities, academic librarians need to coordinate their technical knowhow systematically the technologies in place, the processes, and organizational structure to achieve improved productivity.

Daland (2016), stressed that as knowledge is emerging as the most important "product", it is vital that employee knowledge can be applied to other employees so that the organization can benefit from the collective knowledge available. To do so, different strategies and approaches can be applied. Personal channels, such as apprenticeships or personnel transfers, may be more effective for distributing highly context-specific knowledge whereas impersonal channels, such as knowledge repositories, may be most effective for knowledge that can be readily generalized to other contexts.

According to Avery, et al. (2010), PKM assumes that individuals have developed self-awareness of their limits and abilities- that is what they know and what they can do. This personal self-awareness is an understanding of how much they know, how to access the things they know, strategies for acquiring new knowledge and strategies for 
accessing new information as needed. In the vast amount of information available and many means of acquiring new information, individuals have each mapped out their areas of expertise and their methods for additional learning. Avery et al. further posited that there is increased confidence in one's knowledge and in one's knowledge building capabilities that result from this personal self-understanding. Each individual in an organization acquires confidence in their ability to know or to access or to build the knowledge they need. Whether this acquired knowledge is stored in the form of computer files, filing cabinets, books cases, or in memory, each person acquires and manages her knowledge. The information and knowledge is rarely something that can be owned by the individual, but the organization of information and methods of accessing information is almost and always on a personal basis. The value of the knowledge and the personal management of that knowledge are evident as it is put to use in the organization.

\subsection{Challenges associated with Application of PKM in University Libraries}

The knowledge of human beings is pervasive and scattered in different areas and levels. PKM is therefore faced with many challenges. According to Krebs (2008), negative influences from people, procedures and competitors may occur in the process of knowledge sharing. Raja et al. (2009), mentioned some factors that constitute barriers to seeking, sharing and using knowledge to include lack of trust, fear of loss of power, lack of social network and fear of someone receiving credit for one's knowledge Jain (2011), identified lack of facilities, lack of time and lack of time management as some of the challenges of implementing PKM in university libraries. He was of the view that people cannot perform to their optimum potential if they are not well- equipped with adequate facilities, including new technology.

\section{Methodology}

This study adopted descriptive survey research design to determine the level of awareness and application of personal knowledge management by academic librarians in university libraries in SE Nigeria. The population of this study consisted of 175 academic librarians in all 10 public university libraries in SE Nigeria. The population size is small and as such it was studied in entirety using census sampling. A structured questionnaire was used to collect data for the study. The instrument contained 37 items in two sections of A and B. Section A contained items on demographic data of the respondents. While Section B was divided into three clusters of B1, B2 and B3 according to the research questions with 15,10 , and 7 items respectively. Section B1 contained two options of True or False, while B2 and B3 were structured on a 4-point rating scale. Data collected were analyzed using descriptive and inferential statistics. Frequency counts and percentages were used for research question 1 while arithmetic mean was used for research questions 2 and 3.

\section{Results}

Answering of Research Questions:

Research Question 1: What is the level of awareness of PKM among academic librarians in SE, Nigeria?

Table 1 shows that $71.5 \%, 81.2 \%, 65.5 \%, 86.7 \%, 83.6 \%, 63.0 \%$ and $57.0 \%$ of the respondents were able to correctly identify that items $3,5,6,8,13,14$ and 15 respectively are false statements about PKM and this showed that they have an understanding of the concept of PKM to the extent that they were able to identify the false and misleading information on the concept and responded appropriately, thus exhibiting moderate level of awareness.

Research question 2: What is the level of application of PKM by academic librarians in university libraries in South-East Nigeria? 
Table 1: Level of Awareness of Personal Knowledge Management by academic librarians in university libraries in South-East, Nigeria.

\begin{tabular}{|c|c|c|c|c|c|c|}
\hline & Knowledge management Concepts & True & & False & & Awareness \\
\hline & & Frequency & $\%$ & Frequency & $\%$ & Remarks \\
\hline 1 & $\begin{array}{l}\text { PKM is being aware of the nature of knowledge } \\
\text { one possess. }\end{array}$ & 153 & 92.7 & 12 & 7.3 & $\begin{array}{l}\text { Very High } \\
\text { Level }\end{array}$ \\
\hline 2 & $\begin{array}{l}\mathrm{PKM} \text { is being able to access the knowledge one } \\
\text { possess. }\end{array}$ & 111 & 67.3 & 54 & 32.7 & $\begin{array}{l}\text { Moderate } \\
\text { Level }\end{array}$ \\
\hline 3 & The core focus of PKM is not personal enquiry. & 47 & 28.5 & 118 & 71.5 & High Level \\
\hline 4 & $\begin{array}{l}\text { PKM is about the way individuals collect, manage } \\
\text { and share information at a personal level. }\end{array}$ & 89 & 53.9 & 76 & 46.1 & $\begin{array}{l}\text { Moderate } \\
\text { Level }\end{array}$ \\
\hline 5 & $\begin{array}{l}\text { PKM help to manage group of people's human } \\
\text { capital for professional excellence. }\end{array}$ & 31 & 18.8 & 134 & 81.2 & $\begin{array}{l}\text { Very High } \\
\text { Level }\end{array}$ \\
\hline 6 & $\begin{array}{l}\text { PKM involve a range of relatively complex and } \\
\text { expensive techniques }\end{array}$ & 57 & 34.5 & 108 & 65.5 & $\begin{array}{l}\text { Moderate } \\
\text { Level }\end{array}$ \\
\hline 7 & $\begin{array}{l}\text { PKM produces skillfulness in using various } \\
\text { technologies and tools to access relevant } \\
\text { knowledge. }\end{array}$ & 148 & 89.7 & 17 & 10.3 & $\begin{array}{l}\text { Very High } \\
\text { Level }\end{array}$ \\
\hline 8 & $\begin{array}{l}\text { PKM allow group of people to map out their own } \\
\text { areas of expertise. }\end{array}$ & 22 & 13.3 & 143 & 86.7 & $\begin{array}{l}\text { Very High } \\
\text { Level }\end{array}$ \\
\hline 9 & $\begin{array}{l}\text { PKM is about making individuals recognize their } \\
\text { own value and consequently strive for self- } \\
\text { development }\end{array}$ & 149 & 90.3 & 16 & 9.7 & $\begin{array}{l}\text { Very High } \\
\text { Level }\end{array}$ \\
\hline 10 & $\begin{array}{l}\text { PKM enables one to work out how and when to } \\
\text { process information. }\end{array}$ & 139 & 84.2 & 26 & 15.8 & $\begin{array}{l}\text { Very High } \\
\text { Level }\end{array}$ \\
\hline 11 & $\begin{array}{l}\text { PKM is being able to develop a sourcing strategy } \\
\text { for an individual's ongoing information needs. }\end{array}$ & 94 & 57.0 & 71 & 43.0 & $\begin{array}{l}\text { Moderate } \\
\text { Level }\end{array}$ \\
\hline 12 & $\begin{array}{l}\text { PKM is being able to set criteria for what an } \\
\text { individual want to save or delete. }\end{array}$ & 139 & 84.2 & 26 & 15.8 & $\begin{array}{c}\text { Very High } \\
\text { Level }\end{array}$ \\
\hline 13 & $\begin{array}{l}\text { PKM enables a diverse group of people to locate } \\
\text { the right information quickly. }\end{array}$ & 27 & 16.4 & 138 & 83.6 & $\begin{array}{l}\text { Very High } \\
\text { Level }\end{array}$ \\
\hline 14 & $\begin{array}{l}\text { PKM does not allow an individual to clarify her } \\
\text { information needs for each situation. }\end{array}$ & 61 & 37.0 & 104 & 63.0 & $\begin{array}{l}\text { Moderate } \\
\text { Level }\end{array}$ \\
\hline 15 & $\begin{array}{l}\text { PKM makes an individual unsure of how much } \\
\text { information he needs for an assignment. }\end{array}$ & 71 & 43.0 & 94 & 57.0 & $\begin{array}{l}\text { Moderate } \\
\text { Level }\end{array}$ \\
\hline
\end{tabular}


Table 2: Respondents' Mean Ratings on Level of Application of Personal Knowledge Management by academic librarians in university libraries in South-East Nigeria

$$
\mathrm{N}=165
$$

\begin{tabular}{|c|c|c|c|c|}
\hline $\mathbf{S} / \mathbf{N}$ & ITEMS & Mean & SD & Remarks \\
\hline 1 & $\begin{array}{l}\text { Using meetings or workshops to seek knowledge and } \\
\text { insight from one another }\end{array}$ & 3.24 & .61 & High Level \\
\hline 2 & $\begin{array}{l}\text { Making knowledge request of experts associated with } \\
\text { a particular subject }\end{array}$ & 3.07 & .72 & High Level \\
\hline 3 & $\begin{array}{l}\text { Sharing one's knowledge effectively in meetings, } \\
\text { seminars and conferences }\end{array}$ & 3.04 & .71 & High Level \\
\hline 4 & $\begin{array}{l}\text { Mobilizing one's knowledge for organizational } \\
\text { success }\end{array}$ & 2.98 & .73 & High Level \\
\hline 5 & Identifying and share best practices & 2.78 & .62 & High Level \\
\hline 6 & $\begin{array}{l}\text { Scheduling informal seminars where staff can interact } \\
\text { and exchange "lessons learned", "best practices" and } \\
\text { other specific experience and knowledge }\end{array}$ & 2.32 & .72 & Low Level \\
\hline 7 & $\begin{array}{l}\text { Reviewing projects or activities to enable them to } \\
\text { learn what happened, why it happened and what } \\
\text { lessons can be learned ( after action review) }\end{array}$ & 2.28 & .70 & Low Level \\
\hline 8 & $\begin{array}{l}\text { Keeping inventory and index of expert knowledge } \\
\text { possessed by members of staff }\end{array}$ & 2.15 & .73 & Low Level \\
\hline 9 & $\begin{array}{l}\text { Creating a network of people who share a common } \\
\text { interest and are willing to develop and share that } \\
\text { knowledge (community of practice) }\end{array}$ & 1.83 & .72 & Low Level \\
\hline 10 & Using stories to share knowledge (storytelling) & 1.48 & .57 & Very Low Level \\
\hline & Cluster Mean & 2.51 & & High Level \\
\hline
\end{tabular}

Table 2 shows that five of the ten items listed had mean scores ranging from 2.78 to 3.24 , meaning that they are applied at a high level. One of the remaining five items had a mean score of 1,48 which means very low level while the rest had a mean score of 1.83 to 2.32, showing they are applied at a low level. The cluster mean score of 2.51 shows that academic librarians in university libraries in South-East Nigeria apply PKM at a high level. The standard deviations are within the same range showing that the respondents were homogeneous in their views.

Research question 3: What are the challenges associated with application of PKM by academic librarians in South East University libraries? 
Table 3: Respondents' Mean Ratings on Challenges associated with Application Personal Knowledge Management by Academic Librarians in university libraries in South-East Nigeria

$\mathrm{N}=165$

\begin{tabular}{|c|l|c|c|c|}
\hline S/N & \multicolumn{1}{|c|}{ ITEMS } & Mean & SD & Remark \\
\hline 1 & $\begin{array}{l}\text { Reluctance to share information due to fear of exposing one's } \\
\text { mistakes }\end{array}$ & 3.30 & .53 & Agree \\
\hline 2 & Fear of someone else receiving credit for one's knowledge & 3.28 & .58 & Agree \\
\hline 3 & Lack of awareness of PKM tools and technology & 3.26 & .58 & Agree \\
\hline 4 & $\begin{array}{l}\text { Lack of skills and competencies in personal knowledge management } \\
\text { among librarians }\end{array}$ & 3.11 & .62 & Agree \\
\hline 5 & Lack of trust among employees & 3.07 & .65 & Agree \\
\hline 6 & $\begin{array}{l}\text { Difficulty in expressing tacit knowledge contained in an individual's } \\
\text { head }\end{array}$ & 2.90 & .77 & Agree \\
\hline 7 & Lack of social network & 2.57 & .57 & Agree \\
\hline & Cluster mean & 3.07 & Agree \\
\hline
\end{tabular}

Table 3 shows that the seven items listed had a mean score ranging from 2.57 to 3.30 and cluster mean of 3.07 which means that academic librarians in South- East University libraries agree with the seven items listed as challenges of applying Personal Knowledge Management.

\section{Discussion}

This study examined the level of awareness and application of personal knowledge management by academic librarians in SE Nigeria. The study revealed that the academic librarians in South- East university libraries have a moderate level of awareness of PKM. This implies that academic librarians have basic understanding of the concept of PKM. This finding is in line with the observation of Nwokocha et al. (2015) that the level of awareness of PKM by academic librarians will enable the individuals to identify how much knowledge and information they possess. How they can access the things they know, strategies they can adopt to acquire new knowledge and for accessing new knowledge and ability to understand oneself. They showed an understanding of the concept of personal knowledge management to the level that they were able to identify false and misleading information on the concept and respond appropriately, thus exhibiting a moderate level of awareness. The finding also supports Nwabueze and Obadiya (2017), who reported that the level of awareness of personal knowledge management of special librarians in South West Nigeria was high. However, the finding does not agree with the report of Jain (2011) that the majority of staff in the faculty of humanities, University of Botswana were not aware of the concept.

On level of application of PKM by academic librarians in university libraries in SE Nigeria, the study revealed that there is a high level of application of PKM by academic librarians. This implies that the academic librarians were able to integrate their know-how with the organizational processes in achieving the organization's goals and objectives. This finding is in agreement with Omotaya (2015) who noted that as information managers in the university academic librarians need to systematically coordinate their technical know-how and technologies in place, the processes as well as an organizational structure to achieve to enhance their productivity. This finding is contrary to Nwabueze and Obadiya (2017) who found that there was a low level of application of PKM by special librarians in South West Nigeria.

The finding revealed some challenges that hinder the application of PKM by academic librarians. These challenges range from: lack of social network, reluctance to share information due to fear of exposing one's mistakes, fear of someone else receiving credit for one's knowledge and lack of trust among employees. This supports Nwabueze and Obadiya (2017) who reported that, special librarians in South West experience challenges such as: fear of loss of power, unfavourable organizational culture and lack of social network.

\section{Conclusion and Recommendations}

This study has established that the level of awareness of PKM of academic librarians in university libraries in SE Nigeria is moderate while the level of application is high. This implies that they are conversant with the concepts 
and this affects its application in the university libraries. Engaging them in continuous education programme, professional training courses and workshops will help them to improve.

Based on these findings, the following are recommended.

1. University management should organize continuous education programmes, professional training courses and workshops that will help them to improve their level of awareness and application of PKM.

2. The library and university management should provide social, managerial and technological support to strengthen the implementation of PKM.

3. Library and information science curriculum developers should integrate new concepts like PKM in the curriculum as they evolve to increase the performance of library professionals.

\section{References}

Anklam, P. (2009). KM: Personal knowledge management. Retrieved http:// www.theappgap.com/therd-kmpersonal- knowledge-management.html.

Avery, S., Brooks, R., Browns, J., Dorsey, P. \& O’Conner (2010). Personal knowledge management: framework for integration and partnerships. Retrieved from https:/web.archive.org/web/20101020063459/http:/www. Millikin.edu/PKM/PKM ascue html.

Boom, D. \& Pimentel, T. (2009). A framework for implementing knowledge management. Retrieved from http://www.cclfi.org/files/knowledge\%20 management\%202009.

Daland, H. (2016). Managing knowledge in academic libraries are we? Should we? Liber Quarterly, 26 (1), 28-41.

Igwe, K.N., Nnadozie, C. O. \& Unagha, A.O. (2015). Nature of Knowledge and the Knowledge Economy. In K.N Igwe, C.O. Nnadozie, A.O. Unagha,C.P. Uzuegbu \& M.M. Naga, (eds), Fundamentals of Knowledge Management for Knowledge Economy 1-18.

Jain, P. (2011). Personal knowledge management: the foundation of organizational knowledge management. Retrieved from http://sajlis.journals.ac.za.SAjnl. Library \& information Science 2011, 77(1), 24-38

Krebs, V. (2008). Knowledge networks: mapping and measuring knowledge creation, re-use and flow. Retrieved from http:// www.orgnet.com.

Maponya, P.N. (2004). Km practices in academic libraries: a case study of university of Natal, Pietermaritzburg libraries. Retrieved from http://mapule276883.pbworks.com/f/knowledge \%2bmanagement\%2bpractices.

Moran, B.B. \& Leonard, E. (2010). Academic librarianship. In Marcia, J. Bates and Manny Niles Maack Encyclopedia of Library \& Information Sciences 3rd ed. 1 1-11. London, CRC Press Taylor\& Francis Group.

Nazim, M. \& Mukherjee (2011).Implementing knowledge management in Indian academic libraries. Journal of Knowledge Management Practice, 12 (3). Retrieved from http://www.tlainc.com/artic1269.htm.

Nazim, M. \& Mukherjee (2012). Managing and sharing knowledge in academic libraries. Journal of Knowledge Management Practice, 13 (2) 56-62. Retrieved from http://www.tlaninc.com/artic1305.html.

Nwabueze A.U \& Obadiya, B.T. (2017). Level of awareness and application of personal and organizational knowledge management by special librarians in south west Nigeria. African Journals Online 14 (1) p 154164. Retrieved from https:// www.ajol.info/index.php/ict/article/view/159941

Nwokocha, U., Unagha, A.O, Igwe, K.N. \& Ewah-Out, B.E. (2015). Exploring the Knowledge Economy and the Development of Knowledge Management. In K.N Igwe, C.O. Nnadozie, A.O. Unagha,C.P. Uzuegbu \& M.M. Naga,(eds), Fundamentals of Knowledge Management for Knowledge Economy 52-67.

Ogola, S.A. (2012). Knowledge Management Practices in University Libraries in Kenya. Doctoral thesis submitted to the Department of Library, Records Management and Information Science, School of Information Science, Moi University Kenya.

Omotayo, F.O. (2015). Km as an important tool in organizational management: a review of literature. Library Philosophy and Practice (e-journal) Retrieved from http://digitalcommons.unl.edu./libphilprac/1238.

Raja,W. Z., Ahmad \& AK Sinha (2009). Knowledge management and academic libraries in IT Era: problems and positions. Retrieved from http://crl.du.ac.in/ica109/papers/index-les/ical-124198 4182 RV.pdf. 
Roknuzzaman, M.D. \& Umemoto, K. (2013). How library practitioners view knowledge management in libraries: a qualitative study. Library Management 30 (8/9) 643-656. Retrieved from www.emeraldinsight.com/0143-5124htm.

Verma. S. (2009). Personal knowledge management: a tool to expand knowledge about human cognitive capabilities. ACSIT International Journal of Engineering and Technology. 1(5) 435-438. 